\title{
LUXURY RESTAURANTS IN ROMANIA - AN INNOVATIVE, ELEGANT AND EFFICIENT ONLINE PRESENCE
}

\author{
Andra-Teodora Porumb ${ }^{18}$ \\ Adina Săcara-Onița ${ }^{19}$
}

https://doi.org/10.31410/itema.2018.44

\begin{abstract}
In recent years, the restaurants field has seen spectacular growth in the Romanian economy. More and more restaurant owners have realized the need to promote their business in the online environment as well. In this paper we aim to analyze the strategies by which the restaurants try to attract clientele (Romanians or foreign tourists) through web sites. We analyzed a large number of websites of luxury restaurants in Romania from the point of view of the thematic construction, especially following the way the information is organized, selected and hierarchized, the home page, the name of the company and the motto (the institutional slogan), key words, titration, the link between text and audio-visual documents. We believe that the way in which the company shapes its identity and formulates its discourse is an essential element of advertising strategy and that the originality, creativity and surprise effects generated by the discourse built on website support can attract many customers. On many websites we can see incredible scenarios, titles and collocations in foreign languages (English, French), presentations of the "gastronomic vision" of the master chef. Some websites are translated into English, French, Italian, others contain only English texts - a sign that this restaurant addresses to an elite. Influences of international cuisine, declared or not, also attract a part of their customers, who want to adopt concepts such as fine dining, l'art de vivre à la française or the taste of France or la dolce vita. Being a growing and growing sector, the discourse of restaurant founders and managers offers sometimes spectacular instruments of loyalty and attraction of customers.
\end{abstract}

Keywords: Brand name, brand signature, organizational identity, web site, discourse analysis, interculturalism.

\section{INTRODUCTION}

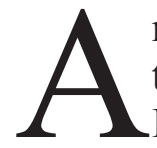

mong the fastest growing sectors of the recent Romanian economy, alongside telecommunications, construction and IT, the restaurant sector is to be found. Investments in this field have been stimulated both as a consequence of global consumption growth, of tourism development, but also due to the financial facilities granted by the Romanian Government (lower VAT in both the food and tourism sectors). Many companies with Romanian private shareholders have been set up, but foreign companies have also entered the market, having spectacular turnovers and creating many jobs.

In addition to the classic, traditional ways of presentation and promotion of restaurants, such as posters, print media and television advertisements, leaflets, flyers, modern communication

\footnotetext{
${ }^{18}$ University of Oradea, Faculty of Economic Sciences, Department of International Business, 1 Universităţii Street, Oradea, 410087, Bihor, Romania

${ }^{19}$ University of Oradea, Faculty of Economic Sciences, Department of International Business, 1 Universităţii Street, Oradea, 410087, Bihor, Romania
} 
channels have also been employed, such as websites, blogs, social networking sites. Many food establishments, especially luxury restaurants, have created their own website, out of the desire to make their business known, to gain authority and credibility, to educate, to gain the loyalty of their customers and even to select them. Besides its informative function (presentation of the business), a site has multiple functions: communication (it updates a style, a tone, an ideology in its discourse), marketing (the site is a means of advertising without spending too much), ecommerce (virtual store), capture (the business will always be able to attract new customers through content and attractive ways of presentation).

This paper analyses the identity in discourse of luxury restaurants as it appears on their websites, the ways of communicating with the customers, the strategies of attracting the customers, and the way of involving clients in the business project.

In our opinion, the main characteristic of the identity in discourse of the luxury restaurants is the intention to create emotion. We are dealing with a discourse infused with subjectivity and interculturality. In fact, a brand that manages to create an emotional bond with consumers will have more chances of success in trying to make known a new product on the market and then in selling it (Lindstrom, 2011: 43). Also, the elegant, novel, original speech, with elements of a show is reflected in the characteristics of the products and services offered by the luxury restaurants. It is about a "promise" of quality, uniqueness, class.

\section{METHODOLOGY}

We will analyze the identity in the discourse of the luxury restaurants by relying mainly on Discourse Analysis and Content Analysis methods. Organizational identity has prompted the interest of many researchers in various fields of study, such as marketing, communication, sociology, psychology. We believe that by bringing together elements of linguistics and discourse analysis, we will be able to identify novel strategies for capturing public attention and attracting new customers.

We will use the concept of thematic construction of the discourse (Florea, 2007), focusing in particular on how the information is organized and prioritized globally (splitting information into pages), page layout (especially the main home page elements such as the name of the restaurant, the logo, the motto or the brand signature), titration, photos. The informative function of the speech is always accompanied by the "capture" function (Charaudeau, 1997), and the images play an important role in the economy of a restaurant's website.

\section{ORGANIZATION OF INFORMATION}

Generally, information is structured on pages that can be accessed using hyperlinks. The menu is easy to follow, in most cases horizontally arranged. The pages that appear in almost all the examined websites are home page, menu, and contact. However, the restaurants are differentiated by introducing intriguing, novel and original pages. Below we will give some examples illustrating the originality and creativity in this area.

The Artist Restaurant is founded by a Dutch established in Romania after an extremely rich international experience. The site, with versions in Romanian and English, proposes 5 pages, the name of each being accompanied by a syntagm that summarizes, qualifies or covers the theme of the page. If, generally speaking, page titles are simple nominal phrases, in this case the title-subtitle organization refers to the techniques used in the print media. The subtitle 
phrase, written in smaller characters, has obvious elements of subjectivity: it qualifies and evaluates the type of food (unique dining), the cuisine (delicious art), the act of cooking (painting with flavors), it includes the enunciator in the message using the possessive adjectives (our) and the possible client by using the personal pronoun (you):

Table 1. The Artist Restaurant

\begin{tabular}{|c|c|c|c|c|}
\hline Home & About & Menu & Gallery & Contact \\
\hline $\begin{array}{c}\text { Unique } \\
\text { dining }\end{array}$ & Our story & Delicious art & $\begin{array}{c}\text { Painting with } \\
\text { flavors }\end{array}$ & Here for you \\
\hline
\end{tabular}

Lacrimi şi Sfinti (Tears and Saints) is the restaurant of a famous Romanian poet, Mircea Dinescu. Lately he has also been the protagonist of a TV show. Mircea Dinescu proposes dishes inspired by local cuisine, reinterpreted, wishing to bring traditional Romanian recipes to the attention of the public, "an almost lost local culinary culture or, at best, ignored for over a century." The website has only a Romanian version. The suggested pages are the following:

\begin{tabular}{|c|c|c|c|c|c|}
\hline POVESTEA & LOCAȚIE & $\begin{array}{c}\text { REZERVĂRI ON- } \\
\text { LINE }\end{array}$ & MÂNCARE & MENIU & CONTACT \\
\hline $\begin{array}{c}\text { (THE } \\
\text { STORY) }\end{array}$ & (LOCATION) & $\begin{array}{c}\text { (ON-LINE } \\
\text { RESERVATIONS) }\end{array}$ & (FOOD) & (MENU) & (CONTACT) \\
\hline
\end{tabular}

Table 2 Lacrimi şi Sfinti (Tears and Saints)

The LOCATION page appears with a good reason as the restaurant is established in a heritage building, where at the beginning of the 20th century there was a fabric shop belonging to famous art collector family, the meeting place of important Romanian painters. The restaurant is a "museum", the dishes are unique, rare, and "precious". The exceptional character of the building, the memory of the important people who went there, the fact that the owner is a man of culture are associated with food as a symbol of the culture and traditions of a people. Food is "a metaphor of culture, class and ethnicity", "the source of memory and tradition", "a marker of identity" (Van der Spuy, 2018: 7).

The website of the Modigliani restaurant (Romanian and English versions) proposes the ITALIAN FLAVOURS page, highlighting the products served and their origin (the flavors, recipes and ingredients of Italy) and counting on authenticity as an essential value:

Table 3. Modigliani, Italian restaurant

\begin{tabular}{l|l|l|l|l}
\hline ABOUT US & MENU & $\begin{array}{l}\text { ITALIAN } \\
\text { FLAVOURS }\end{array}$ & EVENTS & CONTACT US \\
\hline
\end{tabular}

In addition, two links can be accessed: SEE THE SPECIAL MENU; and the RESERVATION link, arranged one on the left, the other on the right side of the page. The second allows access to the reservation page, giving maximum site functionality. To our surprise, we discover that the site has a Romanian, English, but not an Italian version, despite the large number of Italian investors existing in the capital.

We find a similar situation in the case of the Italian restaurant ROBERTO'S, located inside the Hilton Hotel, whose website can be consulted in Romanian and English.

Table 4. ROBERTO'S

\begin{tabular}{|l|r|l|l|l|l|r|}
\hline RESTAURANT & $\begin{array}{r}\text { OUR } \\
\text { MENU }\end{array}$ & CHEF & EVENTS & CENTENNIAL & BLOG & $\begin{array}{r}\text { BOOK } \\
\text { NOW }\end{array}$ \\
\hline
\end{tabular}


The restaurant's website highlights the chef's personality, dedicating a whole page (CHEF) to the exceptional career of a perfect practitioner. The CENTENNIAL page announces the possibility for customers to join the Centennial Club program and to benefit from a series of discounts, and the BLOG page provides recipes, tips and tricks for cooking Italian food.

The Joseph by Joseph Hadad restaurant website has only an English version, which excludes from the very start a wide range of customers and selects a privileged category. It proposes several pages, of which the CONCEPT page is the one that incorporates the philosophy of the business and the founder's vision:

Table 5 Joseph by Joseph Hadad

\begin{tabular}{l|l|l|l|l|l|l|c|l|l}
\hline HOME & CONCEPT & MENU & GALLERY & EVENTS & CENTENNIAL & RESERVATION & $\begin{array}{c}\text { GIFT } \\
\text { VOUCHERS }\end{array}$ & BLOG & CONTACT \\
\hline
\end{tabular}

On this page, the descriptions of the restaurant, its ideology and the presentation of the chef alternate with direct speech sequences. The page opens with the words of the founder and of the master chef. By addressing readers directly, the master chef reveals his personality through a warm speech, very close to potential customers. Direct speech fragments are built after the design of a letter addressed to customers. The beginning and the end of the text belong to Joseph Hadad, who opens himself to the readers:

"I breathe spices and I create them from scratch. I dream every recipe, I wake up in the morning, I draw it and after that I go in the kitchen and cook it. This is the process of every single recipe from the menu." C Chef Joseph Hadad

"Love of my life? Cooking! It flows through my veins and keeps me alive. And I am glad to share it with all of you, at my fine dining restaurant, Joseph by Joseph Hadad".

Joseph Hadad concludes with "Yours truly" and signs as if he addresses the website visitors via a letter.

The concept of the restaurant is illustrated with an emotional lexicon (love, passion) and a lexicon centered on senses and sensations ("I breath spices", "It flows through my veins and keeps me alive"). The chef is an artist, "a forever passionate food lover," combining the "fine dining" style with the concept of "culinary architecture", creating magical things.

Selecting or excluding pages, besides the regular pages of restaurant websites, gives clues to the identity and specificity of luxury restaurants, the concept and vision of their founders. It can focus on the location, the products, the origin of the products, the person who cooks, according to the values of the business and the message they intend to convey: quality, uniqueness, authenticity, tradition, culture, history.

With small exceptions, more specifically when it comes to Romanian restaurants, the websites also have English version, which shows the desire to keep up with times, to adapt to the times we live, addressing an elitist clientele.

\section{HOME PAGE}

Communication specialists recommend that the homepage should have an airy page layout, an elegant design, a title, a logo, a little, essential but valuable information, a few well-chosen and high-quality images, a representative background image, and links to other pages. The home 
page has the role of introducing and guiding the reading. If the page is well done, the business manages to build its credibility from the very start.

In the case of all the examined websites, all these recommendations are observed. At the top of the main page, important elements of the thematic construction of the identity in discourse appear. They are the name of the restaurant, its slogan, the logo. The home page includes photos and warm colors, the image having a primary role in attracting public attention.

Here the purpose of capturing the company's speech has a more important role than the information purpose (Charaudeau, 2005). In order to find out information, the customer who visits the site is encouraged to access the internal pages, to become a loyal visitor of the website and a permanent customer of the brand.

The minimal elements of the home page are the name of the restaurant, some photos and links to the internal pages.

The Artist Restaurant (the name of the restaurant, two photos succeeding one another, representing the chef at work and a serving dish made by him, a horizontal menu bar at the top of the page)

Other items that appear on the home page are the logo, the motto, and the advertising slogans:

Meze Taverna (the logo consisting of the name of the company written in Greek characters, a succession of photos representing the restaurant - exterior and interior - and the products served, on the left a vertical menu bar, containing symbols, without titles);

Roberto's Restaurant (the name of the restaurant, the motto, a background image representing the interior of the restaurant, overlaying a photo of the restaurant's room, two pictures representing the customers, a photo of a serving dish and the phone number for reservations, a horizontal menu bar at the top of the page); here the images also function as links to other pages of the website;

Modigliani. Italian Restaurant (the restaurant name, a background image representing a serving dish, the motto, an impact phrase, and a call to action, a horizontal menu bar at the top of the page plus two buttons placed under the menu bar, also for access to internal pages);

Joseph by Joseph Hadad (at the top of the page: to the left, the founder's and owner's signature, followed by a horizontal menu bar, a background image representing part of the restaurant's room, the restaurant name, a welcome phrase, and another phrase defining the concept of the business).

Generally, the home page is elegant, airy; the photos create excitement and subtly complement the text, encouraging site navigation.

\section{BRAND NAME, BRAND SIGNATURE}

Brand names have a "privileged role in the communication media universe", being associated with the "brand image" the company is constantly acting upon (Maingueneau, 2005). They reflect the culture, the identity, the mission of the business offering the products or services. They are often accompanied by the brand signature, the motto or the institutional slogan (tagline in the USA, baseline in the United Kingdom, signature de marque in France), a syntagm that synthesizes the economic strategy or brand promise. 
These elements have a major place in the website's economy: generally, the restaurant name and the motto appear on the home page; in some sites there are elements that are present on each page; sometimes the motto appears only on certain pages, especially on the presentation pages of the chef or on the Cuisine pages.

These important elements of the thematic building of identity in discourse, which mainly have informative and advertising function, rely on creating the surprise element. They are small, transparent texts, but must be equipped with a great "evocative power" (Charaudeau 2005), first to attract attention, then to remain in the public's memory.

Hammer (2018) notes that, in order to stand out, especially in the fashion, luxury and restaurant sectors, the company's name is trying to innovate through unexpected, original and memorable names that highlight the business and its vision.

One of the strategies commonly used is the association of some areas of activity. The most used is the cuisine \& art association. The restaurant is a "creative workshop", and the chef is an "artist", a painter, a sculptor. Thus, the essentials of the cuisine concept are emotion and expression, just as with fine arts. Art becomes a source of inspiration, a model, and a goal. Therefore, the products will have the character of uniqueness, excellence, surprise. Using isotope art is one of the main discursive strategies of the restaurant branding, and creativity is part of the promise of these brands.

Table 6. Cuisine \& Art

\begin{tabular}{|l|l|}
\hline RESTAURANT NAME & \multicolumn{1}{c|}{ BRAND SIGNATURE } \\
\hline The Artist Restaurant & $\begin{array}{l}\text { Imaginative \& Emotional, Artistic \& } \\
\text { Playful, Inspired \& Innovative. These } \\
\text { are the words that define us. }\end{array}$ \\
\hline L'Atelier (The Workshop) & L'art culinaire (The culinary art) \\
\hline Modigliani. Italian restaurant & $\begin{array}{l}\text { Trăieşte plăcerea gustului (Experience } \\
\text { the pleasure of taste) }\end{array}$ \\
\hline
\end{tabular}

The first name highlights the image of the chef, the artist; the second one refers to the place where the products are created. Trends are also written in the isotope of art, the former using qualifying adjectives from the lexical field of art (imaginative, inspired), the latter employing them explicitly (gastronomy is an art).

The website of the L'Atelier restaurant has a Romanian version and an English version. The name and motto remain in French, though, evoking not only the French gourmet tradition recognized worldwide - but also a whole set of qualities specific to the French cultural space. It is not by accident that in the last years there is talk of haute cuisine, according to the model of phrase haute couture (from here, the cuisine-mode association).

The third example illustrates a special choice for a restaurant name. Choosing the name of a famous painter confers extremely many chances for the public to easily remember the name. At the same time, it raises the interest for that establishment. The brand signature refers to pleasant senses and sensations, contains emotion lexeme (pleasure), helping to create a positive image. In fact, it is followed by a call to action, focused on the client, a call that works with the same positive vocabulary and uses lexemes that qualify (authentic) or positively assess (exquisite) (,Încearcă meniul nostru rafinat cu o autentică savoare italiană, pregătit de către un Bucătar Şef 
italian. Delectează-ţi simţurile şi răsfaţă-te!” / „Taste our exquisite menu with an authentic Italian touch, designed by our Italian Executive Chef. Delight your senses and spoil yourself!').

In the following example, the Italian name does not have the connotations mentioned above and does not evoke luxury, but rather a small, familiar space, in contrast to the English slogan referring to art, modernity and a creative cooking style:

Table 7. Cuisine \& Design

\begin{tabular}{|c|c|}
\hline RESTAURANT NAME & BRAND SIGNATURE \\
\hline Baracca & Design food \\
\hline
\end{tabular}

We also notice the existence of poetic names. This time the cuisine $\&$ art association is replaced by the combination of cuisine \& literature. The name „Lacrimi şi Sfinţi" (Tears and Saints) alludes to emotions and literature, and also has a "recreational" function (Hammer, 2018). This name, which creates a surprise effect, is itself a brand signature. The interpretation of the name of the restaurant implies knowledge of the owner's work (Mircea Dinescu). In fact, in the opening of the restaurant menu there is a poem written by him: „Bucătăriile se văd din cer / Mai bine decât oamenii de seamă / Prinzi îngeru-n gamela ta cu zeamă [...]" ("The kitchens are seen from heaven / Better than the notable men / You can catch an angel in your canteen full of soup $[\ldots]^{\prime \prime)}$.

Table 8. Cuisine \& Literature

\begin{tabular}{|c|c|}
\hline RESTAURANT NAME & BRAND SIGNATURE \\
\hline Lacrimi şi Sfinţi (Tears and \\
Saints)
\end{tabular}

A frequent choice for restaurant names is the use of proper names. The first names of the founder are frequently used. In the following examples appear, Robert Bayer, the founder of Roberto's Restaurant in Amsterdam, and Joseph Hadad, a 40-year international experience chef who was also the protagonist of some TV shows in Romania. These personalities are themselves a brand:

Table 9. The Founder

\begin{tabular}{|l|l|}
\hline RESTAURANT NAME & \multicolumn{1}{|c|}{ BRAND SIGNATURE } \\
\hline Roberto's & $\begin{array}{l}\text { Pura cucina italiana (Genuine Italian } \\
\text { cuisine) }\end{array}$ \\
\hline Joseph by Joseph Hadad & $\begin{array}{l}\text { Contemporary fine dining, intimate } \\
\text { space, author recipes and an art deco } \\
\text { style }\end{array}$ \\
\hline
\end{tabular}

Just as the name Roberto refers to the Italian cultural space, being an extremely frequent name, the slogan contains the phrase "cucina italiana", which became a gourmet brand, preceded by the "pura" rating. We find the idea of authenticity, the return to the origins, the valorization of the history, traditions and culture of a people.

In the second case, the business signature contains four elements that define the restaurant. 
Table 10. Cuisine \& Histoire

\begin{tabular}{|c|c|}
\hline $\boldsymbol{R E S T A U R A N T} N \boldsymbol{A M E}$ & $\boldsymbol{B R} \boldsymbol{A N D} \boldsymbol{S I G N A T U R E}$ \\
\hline Casa Antinori & Un restaurant unde arta culinară \\
& $\begin{array}{c}\text { întâlnește aspectul rafinat toscanian } \\
\text { (A restaurant where the culinary art } \\
\text { meets the refined Tuscan look) }\end{array}$ \\
\hline
\end{tabular}

Sometimes, a famous family name is chosen, as in the case of the Italian restaurant Casa Antinori. The Antinori family was famous in Tuscany for the production of quality wine, with a tradition of more than 600 years.

Even if these luxury restaurants are located in the capital or in the major cities of Romania, most of the names and mottos are written in foreign languages: English, French, and Italian. Generally, these are international, French or Italian restaurants that offer products of very highquality created by chefs who have graduated from famous schools or who are themselves school founders. The message sent by the combination of name \& motto expressed in foreign languages is generally the following: we are the representatives of the gastronomy elite; our clientele is part of the elite of society or wants this, wishes for a better life, is open to the world and willing to adopt the French, Italian, English lifestyles, etc.

\section{CONCLUSION}

Analyzing the identity in discourse of luxury restaurants and how the information on the websites are presented and prioritized, we noticed the desire of each establishment to create a strong brand image, to build their credibility in a context of intercultural communication and to stand out from other establishments in a highly competitive environment.

We identified some elements of the discursive strategy of these businesses, namely the selection of information to put them forward, the attractive presentation of information, the creation of isotopes and the novel associations (cuisine $\&$ art, cuisine $\&$ mode, cuisine $\&$ literature, the chef is a painter, a sculptor, a designer), the choice of original scenography and the use of a significant number of markers of subjectivity: positive vocabulary, emphasis on elements with qualification and evaluation function (the dishes are "delicious sculptures", the menu "unique", the culinary experience equals to the "conversion into an experience of emotions"), focusing on the client and his wishes.

Restaurant discourse has a strong persuasive power. On the one hand, the pool of common knowledge of a people is successfully exploited, calling for history, culture, traditions, rituals, religion. On the other hand, intercultural communication proves to be a winning strategy for the luxury restaurants sector. Their discourse contains many elements of multiculturalism and sells "hope in many forms" (Lindstrom, 2013), promising a healthier, better, more beautiful, more luxurious life (fine dining, la dolce vita, the taste of France).

Behind the obvious commercial motivation, we find a coherent and harmonious discourse on these websites. Choosing a name, a logo, a motto, distributing information on pages, selecting and merging titles and images, they are all driven by a red thread that reflects the vision of the owners and of the marketing specialists, the concept and style of the brand. 


\section{REFERENCES}

[1] Adam, J.-M. (1997) L'argumentation publicitaire, Nathan Université, Paris.

[2] Adam, J.-M. (1999) Linguistique textuelle. Des genres de discours aux textes, Nathan, Paris.

[3] Balmer, J.M.T., Greyser S. (2003), Revealing the Corporation: Perspectives on Identity, Image, Reputation, Corporate Branding and Corporate Level Marketing, Routledge, London.

[4] Charaudeau, P. (1997) Le discours d'information médiatique. La construction du miroir social, Nathan/INA, Paris.

[5] Charaudeau, P. (2005) Les médias et l'information. L'impossible transparence du discours, De Boeck Université, Bruxelles.

[6] Compatangelo, R. (1980) Che cos'è uno slogan? Paravia, Torino.

[7] Florea, L.S. (1993) «Pour une lecture thématique des médias, intitulés de presse et slogans publicitaires ", SIRIUS, $\mathrm{n}^{\circ} 1$, Actele colocviului internaţional " Communiquez, communiquez ... », pp. 17-37.

[8] Florea, L.S. (2007), « La construction thématique, générique et textuelle de l'événement. Un modèle d'analyse du discours journalistique », Studia UBB, Ephemerides, LII, n 2 , pp. 3-27.

[9] Hammer, F. (2018) «La créativité verbale dans l'espace urbain : l'exemple de l'enseigne commerciale ", Jeux de mots et créativité, pp. 251-270, [Online], Available: https://www.researchgate.net/publication/328147506_La_creativite_verbale_dans_l'espa ce_urbain_l'exemple_de_l'enseigne_commerciale_Langues_discours_et_litterature.

[10] Kerbrat-Orecchioni, C. (1980) L'énonciation. De la subjectivité dans le langage, Armand Colin, Paris.

[11] Lindstrom, M. (2011) Buyology, Publica, Bucureşti.

[12] Lindstrom, M. (2013) Brand Washed. Trucuri prin care companiile ne manipulează minţile şi ne conving să cumpărăm, Publica, Bucureşti.

[13] Maingueneau, D. (2005) Analyser les textes de communication, Armand Colin, Paris.

[14] Navarro Domínguez, F. (2005) « La rhétorique du slogan: cliché, idéologie et communication », Bulletin Hispanique, tome 107, n 1, pp. 265-282.

[15] Palma, S. (2005) «Un aspect de la communication institutionnelle: les slogans des banques ", Bulletin Hispanique, tome 107, n 1, pp. 255-264.

[16] Pélissier, D. (2015) « Les organisations ont-elles ont une identité numérique? », Présence numérique des organisations, [Online], Available : http://presnumorg.hypotheses.org/34.

[17] Popescu, M. (2008) «Site-ul web : Între modalitate de comunicare și instrument strategic de marketing », Revista de marketing Online, vol. 2, nr. 1, pp. 39-45.

[18] Porumb, A.T. (2016) " Mise en thème de l'identité organisationnelle : le cas du site web », Analele Universităţii din Oradea (Seria Ştiinte Economice), tom XXV, Vol. II, pp. 149157.

[19] Porumb, A.T., Porumb, C. (2017) « Stratégies de construction d'un discours positif. Le cas des sites web des praticiens de l'art dentaire », Journal of Languages for Specific Purposes, $\mathrm{n}^{\circ} 4$, pp. 77-92.

[20] Rovenţa-Frumuşani, D. (2005) Analiza discursului. Ipoteze şi ipostaze, Tritonic, Bucureşti.

[21] Soulages, J.C. (2013) «L'ordre du discours publicitaire», Semen [En ligne], 36 | 2013, mis en ligne le 23 avril 2015, consulté le 06 avril 2018. URL : http://journals.openedition.org/semen/9638.

[22] Van der Spuy, A. (2018) "Food as a Marker of Identity in My Beautiful Death by Eben Venter", Athens Journal of Philology, Volume 5, Issue 1, pp. 7-18. 